Postgraduate Bosowa University Publishing (PBUP)
Indonesian Journal of Business and Management
e-ISSN: $2460-3767 \quad p$-ISSN: $2656-6885$
inttps://postgraduate.universitasbosowan
JOURAL

\title{
PENGARUH KOMPETENSI DAN KEDISIPLINAN TERHADAP KINERJA APARATUR PENGAWASAN INTERN PEMERINTAH (APIP) MELALUI KEPUASAN KERJA PADA KANTOR INSPEKTORAT KABUPATEN BARRU
}

\section{The Effect Of Competence And Discipline On The Performance Of The Government Internal Supervision Apparatus (APIP) Through Job Satisfaction In The Inspectorate Office Barru District}

\author{
Muhammad Mufti Abyan, Oesman Lewangka², Miah Said ${ }^{2}$ \\ ${ }^{1}$ Inspektorat Daerah Kabupaten Barru \\ ${ }^{2}$ Program Studi Manajemen Program Pascasarjana Universitas Bosowa
}

Email: muftiabyan @gmail.com

Diterima: 26 Oktober 2021/Disetujui: 24 Desember 2021

\begin{abstract}
ABSTRAK
Tujuan dari penelitian ini adalah mengetahui dan menganalisis pengaruh kompetensi, kedisiplinan terhadap kepuasan kerja dan kinerja APIP, pengaruh kepuasan kerja terhadap kinerja, pengaruh kompetensi dan kedisiplinan terhadap kinerja APIP melalui kepuasan kerja. Teknik pengumpulan data melalui kuesioner, observasi, interview dan dokumentasi, dengan teknik analisis data menggunakan analisis jalur, pengujian hipotesis dan analisis sobel test. Hasil penelitian menemukan bahwa kompetensi dan kedisiplinan memberikan pengaruh secara nyata terhadap peningkatan kepuasan kerja, kompetensi dan kedisiplinan memberikan dampak terhadap peningkatan kinerja pegawai. Kepuasan kerja memberikan pengaruh nyata terhadap kinerja APIP. Kepuasan kerja dapat memediasi pengaruh secara parsial kompetensi dan kedisiplinan terhadap kinerja APIP.
\end{abstract}

Kata Kunci: Kompetensi, Kedisiplinan, Kepuasan Kerja Dan Kinerja APIP

\begin{abstract}
The purpose of this study was to determine and analyze the influence of competence, discipline on job satisfaction and performance of APIP, the effect of job satisfaction on performance, the influence of competence and discipline on APIP performance through job satisfaction. The data were collected through questionnaires, observation, interviews and documentation, with data analysis techniques using path analysis, hypothesis testing and sobel test analysis. The results of the study show that competence and discipline had a significant effect on increasing job satisfaction, competence and discipline had an impact on improving employee performance. Job satisfaction has a real influence on Apip's performance. Job satisfaction can partially mediate the influence of competence and discipline on APIP's performance.
\end{abstract}

Keywords: Competence, Discipline, Job Satisfaction And APIP Performance.

(c) ()

\section{PENDAHULUAN}

Pengawasan intern pemerintah merupakan fungsi manajemen yang penting dalam penyelenggaraan pemerintah. Melalui pengawasan intern dapat diketahui apakah suatu instansi pemerintah telah melaksanakan kegiatan sesuai dengan tugas dan fungsinya secara efektif dan efisien, serta sesuai dengan rencana, kebijakan yang telah ditetapkan, dan ketentuan. Selain itu pengawasan intern atas penyelenggaraan pemerintahan diperlukan untuk mendorong terwujudnya good governance dan clean government dan mendukung penyelenggaraan pemerintahan yang efektif, efisien, transparan, akuntabel serta bersih dan bebas dari praktik korupsi, kolusi, dan nepotisme. Oleh karena itu mewujudkan pemerintahan yang baik merupakan suatu keharusan bagi pemerintah, masyarakat dan DPR sebagai pemangku kepentingan dalam suatu negara. 
Seiring dengan berubahnya paradigma, pegawai selaku pihak yang terkena dampak dari perubahan dan pelaku perubahan tersebut harus dapat meningkatkan kinerjanya. Peran sebagai Aparatur Pengawas Internal Pemerintah (APIP) dalam melakukan pengawasan dan pembinaan membutuhkan kinerja pegawai yang baik.

Kinerja menurut Mangkunegara (2017:67) adalah prestasi kerja atau prestasi sesungguhnya yang dicapai oleh seseorang, atau dengan kata lain hasil kerja secara kualitas dan kuantitas yang ingin dicapai oleh seorang pegawai dalam melaksanakan tugasnya sesuai dengan tanggungjawab yang diberikan kepadanya. Semakin tinggi kinerja pegawai maka semakin baik kinerja organisasi tersebut dalam pencapaian visi dan misi organisasi.

Oleh karena itu berhasil atau tidaknya suatu organisasi dalam mencapai tujuannya tergantung keberhasilan dari pada individu atau pegawai pada organisasi itu sendiri dalam menjalankan tugas mereka melalui kepuasan kerja yang dirasakan oleh setiap pegawai dari hasil kerja atau kinerja yang dicapai oleh organisasi. Kinerja pegawai dalam menjalankan fungsinya tidak berdiri sendiri tapi berhubungan dengan kepuasan kerja yang dirasakan oleh pegawai. Hal ini sesuai dengan teori yang dikemukakan oleh Robbins (2015:91) bahwa kepuasan kerja merujuk kepada sikap umum seorang individu atau karyawan terhadap pekerjaan yang dilakukannya. Seseorang dengan tingkat kepuasan kerja tinggi menunjukkan sikap yang positif terhadap kerja itu sendiri, sedangkan seseorang yang tidak puas dengan pekerjaannya menunjukkan sikap yang negatif terhadap pekerjaan itu. Sehingga dapat dikatakan bahwa kepuasan kerja yang tinggi akan berpengaruh terhadap kinerja karyawan, hal ini sesuai dengan pendapat yang dikemukakan oleh Sinambela (2012:255) yang mengatakan bahwa kepuasan kerja berkaitan erat dengan kinerja karyawan.

Untuk meningkatkan kepuasan dan kinerja APIP, maka dalam penelitian ini difokuskan pada masalah kompetensi dan kedisiplinan. Kompetensi mempengaruhi kepuasan kerja, sesuai teori yang dikemukakan oleh Rivai dan Sagala (2010:856) bahwa kompetensi yang dimiliki oleh karyawan sangat penting dalam pencapaian tujuan organisasi dan memotivasi para karyawan untuk memberikan yang terbaik agar mendapat kepuasan tersendiri dalam melakukan pekerjaannya. Penelitian Ngebu, dkk. (2018) hasil analisis membuktikan bahwa kompetensi berpengaruh positif dan signifikan terhadap kepuasan kerja.

Selain kompetensi berpengaruh terhadap kepuasan kerja, juga berpengaruh terhadap kinerja pegawai, sebagaimana yang dikemukakan oleh Prawironegoro dan Utari (2016:113) menjelaskan bahwa kompetensi merupakan perpaduan keterampilan, pengetahuan, kreativitas, dan sikap positif terhadap pekerjaan tertentu yang diwujudkan dalam pencapaian kinerja. Susanto
(2016) mengemukakan bahwa kompetensi berpengaruh terhadap kinerja pegawai.

Kemudian disiplin kerja berpengaruh terhadap kepuasan, dimana menurut Hamali (2016:214) mengemukakan bahwa disiplin kerja adalah suatu kekuatan yang berkembang di dalam tubuh karyawan dan menyebabkan karyawan dapat menyesuaikan diri dengan sukarela pada keputusan peraturan, dan nilai-nilai tinggi dari pekerjaan dan perilaku. Disiplin kerja merupakan suatu faktor yang penting dalam meningkatkan kepuasan kerja karena disiplin merupakan sesuatu yang penting untuk organisasi dalam menciptakan efektifitas terhadap pekerjaan. Seseorang yang mempunyai disiplin kerja yang tinggi akan bekerja dengan baik tanpa adanya pengawasan. Hendra Hadiwijaya (2016) hasil temuan bahwa disiplin kerja berpengaruh langsung terhadap kepuasan kerja pegawai.

Kemudian disiplin kerja sangat berpengaruh terhadap kinerja pegawai, sebagaimana dikemukakan oleh Hartatik (2014:212) bahwa disiplin kerja yang baik mencerminkan besarnya tanggungjawab seseorang terhadap tugas-tugas yang diberikan kepadanya. Jadi, dapatlah dikatakan bahwa disiplin kerja memiliki andil yang sangat besar terhadap kinerja seorang pegawai. Disiplin merupakan sikap karyawan dalam menghormati, menghargai dan taat terhadap tata tertib organisasi. Disiplin merupakan salah satu hal yang harus terus dijaga dan ditingkatkan secara terus menerus agar karyawan menjadi terbiasa bekerja sesuai aturan. Rizal S, dkk. (2019) hasil temuan bahwa disiplin kerja berpengaruh positif dan signifikan terhadap kinerja pegawai.

Penelitian ini menentukan kepuasan kerja sebagai variabel mediasi antara pengaruh kompetensi terhadap kinerja, dimana kepuasan kerja pada dasarnya merupakan sesuatu yang bersifat individual pada aspek yang sama. Setiap individu memiliki tingkat kepuasan yang berbedabeda sesuai dengan sistem nilai yang berlaku pada dirinya. Makin tinggi penilaian terhadap pekerjaan yang dirasakan sesuai dengan kompetensi individu, maka makin tinggi kepuasannya terhadap pekerjaan tersebut sehingga berdampak terhadap kinerja karyawan (Rivai dan Sagala, 2018:856). Penelitian Yulianto (2017) menyatakan bahwa pegawai yang memiliki kompetensi berpengaruh secara signifikan terhadap kinerja baik secara langsung maupun tidak langsung melalui kepuasan kerja. Hal ini memperlihatkan bahwa saat kompetensi yang dimiliki pegawai membaik, maka akan semakin baik pula kinerja pegawai sehingga berdampak terhadap kepuasan kerja yang dirasakan oleh pegawai.

Kemudian kepuasan kerja dapat memediasi pengaruh antara kedisiplinan terhadap kinerja, sebagaimana dikemukakan oleh Hasibuan (2019:193) bahwa kedisiplinan adalah kesadaran dan kesediaan seseorang menaati semua peraturan perusahaan dan norma-norma sosial yang berlaku untuk meningkatkan kesadaran dan kesediaan seorang karyawan dalam mentaati peraturan perusahaan dan norma-norma sosial 
yang berlaku. Muamar (2019) dimana temuan penelitian bahwa kepuasan kerja dapat memediasi pengaruh antara disiplin kerja terhadap kinerja pegawai. Dimana apabila karyawan dapat melaksanakan tugasnya dengan penuh kesadaran serta dapat mengembangkan tenaga dan pikirannya semaksimal mungkin maka tujuan organisasi akan terwujud, sehingga hal ini dapat memberikan kepuasan kerja bagi pegawai.

Pentingnya masalah kompetensi dan kedisiplinan, maka peneliti menentukan obyek penelitian pada Kantor Inspektorat, Kabupaten Barru, sebagai instansi yang memiliki fungsi dalam melakukan pengawasan kinerja Pemerintahan daerah, maka dituntut kinerja kerja yang tinggi. Kinerja pegawai Inspektorat Kabupaten Barru sebagai pengawas internal merupakan hal yang penting, karena mengawasi pelaksanaan tugas SKPD dan Kabupaten/Kota, diantaranya yaitu menentukan apakah prosedur yang ditetapkan oleh manajemen puncak (Gubernur) telah dipatuhi dan berjalan sesuai dengan rencana, menentukan baik atau tidaknya pemeliharaan terhadap kekayaan daerah, menentukan efisiensi dan efektivitas prosedur dan kegiatan pemerintah daerah, serta yang tidak kalah pentingnya adalah menentukan keandalan informasi yang dihasilkan oleh berbagai Unit/Satuan Kerja sebagai bagian yang integral dalam organisasi Pemerintah Daerah. Seluruh pelaksanaan pekerjaan tersebut terwujud dalam output berupa Laporan Hasil Pengawasan.

Salah satu hal yang ingin dicapai adalah mencegah terjadinya penyimpangan dalam pelaksanaan manajemen Pemerintahan daerah. Kemudian fungsi lainnya adalah dengan melakukan pengawasan, pemeriksaan, penilaian dan pengusutan atas dua asas, yaitu : Badan Pengawasan Daerah Provinsi sebagai wujud vertikalnya, dan Bupati sebagai sumber penerimaan tugas, sehingga untuk menunjang pelaksanaan tenaga APIP untuk melaksanakan visinya yakni : Mewujudkan Pemerintahan yang Baik, Pengawasan yang Profesional dan Taat Azas Laporan Akuntabilitas Instansi Pemerintah, maka diperlukan kinerja yang tinggi dari masing-masing APIP. Namun permasalahan yang terjadi bahwa kinerja APIP belum optimal, yang disebabkan karena kurangnya kepuasan kerja yang dirasakan oleh pegawai, kurangnya kompetensi dan kedisiplinan pegawai dalam menjalankan aktivitas kerja sehari-hari. Hal ini dapat dilihat dari kurangnya insentif-insentif dan tunjangan kinerja, serta kurangnya kerjasama antara sesama rekan kerja sehingga menyebabkan pegawai APIP kurang puas dalam bekerja, kemudian kurangnya pengetahuan dan kemampuan pegawai terkait dalam hal pengawasan, serta masih tingginya tingkat absensi pegawai APIP, dimana masih banyak yang sering terlambat masuk kantor, sering minta izin dan tidak tepat waktu dalam bekerja.

\section{METODE}

a. Jenis Penelitian
Pendekatan yang digunakan peneliti adalah pendekatan kuantitatif, merupakan salah satu jenis kegiatan penelitian yang spesifikasinya adalah sistematis, terencana, dan terstruktur dengan jelas sejak awal hingga pembuatan desain penelitian, baik tentang tujuan penelitian, subjek penelitian, objek penelitian, sampel data, sumber data, maupun metodologinya (mulai pengumpulan data hingga analisis data). Penelitian kuantitatif adalah penelitian yang menekankan pada pengujian teori melalui pengukuran variabel-variabel penelitian dengan angka dan melakukan analisis data dengan prosedur statistik. Dalam penelitian ini, peneliti mengarahkan pada kenyataan-kenyataan yang berhubungan dengan kompetensi, kedisiplinan terhadap kinerja APIP melalui kepuasan kerja pada Kantor Inspektorat, Kabupaten Barru

\section{b. Populasi dan Sampel}

Populasi dalam penelitian ini seluruh pegawai pada Kantor Inspektorat, Kabupaten Barru yakni berjumlah sebesar 34 orang pegawai APIP, sedangkan penarikan sampel dengan menggunakan metode sensus, dimana menurut Sugiyono (2016:78) adalah teknik penentuan sampel bila semua anggota populasi digunakan sebagai sampel, hal ini sering dilakukan bila jumlah populasi relatif kecil, kurang dari 30 orang, maka jumlah populasi dapat diambil sebagai jumlah keseluruhan populasi yang akan diteliti, sehingga jumlah sampel dalam penelitian ditetapkan sebesar 34 orang.

\section{c. Variabel Penelitian}

Variabel penelitian merupakan konsep yang mempunyai variasi nilai-nilai, yaitu adanya variabel dependent dan independent serta variabel antara. Variabel dependent atau disebut variabel terikat adalah variabel yang dipengaruhi atau disebabkan adanya variabel independent. Sedangkan variabel independent adalah variabel yang mempengaruhi variabel dependent. Variabel-variabel dalam penelitian ini adalah :

1) Variabel $X$ (Variabel Independent) adalah kompetensi dan kedisiplinan.

2) Variabel Y (Variabel Dependent) adalah kinerja APIP

3) Variabel Z (Variabel antara) adalah kepuasan kerja.

\section{d. Teknik Pengumpulan Data}

Teknik pengumpulan data yang dilakukan pada penelitian ini adalah menggunakan metode kuesioner. Metode kuesioner adalah teknik pengumpulan data yang dilakukan dengan cara memberi seperangkat pertanyaan atau pernyataan tertulis kepada responden untuk dijawabnya. Tehnik pengumpulan data yang digunakan dalam penelitian ini adalah :

1. Questionare

Questionare yaitu teknik pengumpulan data yang dilakukan dengan cara menyebarkan selebaran questionare (angket) untuk diisi kepada responden yang menjadi sampel dalam penelitian ini.

2. Observasi

Teknik pengumpulan data yang dilakukan melalui hasil pengamatan secara langsung pada obyek 
penelitian terutama mengenai kompetensi, kedisiplinan terhadap kinerja APIP melalui kepuasan kerja pegawai pada Kantor Inspektorat, Kabupaten Barru.

3. Interview

Teknik pengumpulan data yang dilakukan dengan melakukan wawancara dan tanya jawab secara langsung dengan beberapa bagian yang terkait dan sejumlah pegawai yang dijadikan sampel dalam penelitian ini.

4. Dokumentasi

Dokumentasi yakni tehnik pengumpulan data yang dilakukan dengan cara mengumpulkan sejumah data-data tertulis, dokumen-dokumen penting baik yang berasal dari pada Kantor Inspektorat, Kabupaten Barru maupun yang berasal dari sejumlah literatur dan bahan pustaka.

\section{e. Jenis dan Sumber Data}

Jenis data yang dikemukakan dalam penelitian ini bersumber dari data kualitatif dan kuantitatif yaitu :

a. Data kualitatif adalah data yang berbentuk kalimat, kata atau gambar seperti gambaran umum lokasi penelitian, visi dan misi serta uraian tugas masingmasing bagian.

b. Data kuantitatif adalah data yang berbentuk angkaangka termasuk data kualitatif yang diangkakan (skoring) atau data yang diperoleh dari hasil pengukuran.

Sumber data yang digunakan dalam penelitian ini berupa data primer dan data sekunder, sebagai berikut :

a. Data primer adalah data yang diperoleh atau dikumpulkan secara langsung di lapangan oleh orang yang melakukan penelitian. Sumber data primer dalam penelitian ini adalah hasil jawaban responden atas kuesioner/angket yang diberikan kepada responden

b. Data sekunder adalah data yang diperoleh dari pihak lain atau tidak langsung diperoleh dari subyek penelitian. Data sekunder yang digunakan dalam penelitian ini adalah sumber data yang didapat dari Kantor Inspektorat, literatur, karangan ilmiah, jurnal-jurnal serta data lainnya yang ada

\section{f. Teknis Analisis Data}

Setelah data dikumpulkan dan diolah, proses selanjutnya adalah melakukan pengujian dengan menggunakan analisis jalur yang merupakan perluasan dari analisis regresi, atau penggunaan analisis regresi untuk menaksir hubungan kausalitas antar variabel yang telah ditetapkan. Adapun metode yang digunakan adalah :

\section{Uji instrument penelitian}

a. Uji validitas digunakan untuk mengukur sah atau valid tidaknya suatu kuesioner. Uji validitas dilakukan dengan melakukan korelasi bivariate antara masing-masing skor indikator dengan total skor variabel. Suatu variabel dikatakan valid jika memberikan nilai korelasi di atas dari nilai standar $(0,30)$. b. Uji reliabilitas dimaksudkan untuk mengukur suatu kuesioner yang merupakan indikator dari variabel. Reliabilitas diukur dengan uji statistik cronbach's alpha $(\alpha)$. Suatu variabel dikatakan reliabel jika memberikan nilai cronbach' alpha $>0,60$.

2. Analisis jalur (Path analysis) dengan metode regresi linear berganda yang digunakan untuk menguji pengaruh kompetensi dan kedisiplinan terhadap kinerja aparatur Pengawasan Intern melalui kepuasan kerja. Berikut ini adalah persamaan dalam analisis jalur menurut Sunyoto (2015:204), dengan menggunakan rumus :

$$
\begin{array}{ll}
\mathrm{Y}_{1}= & \beta_{0}+\beta_{1} \mathrm{X}_{1}+\beta_{2} \mathrm{X}_{2}+\mathrm{e} \\
\mathrm{Y}_{2}= & \beta_{0}+\beta_{1} \mathrm{X}_{1}+\beta_{2} \mathrm{X}_{2}+\beta_{3}+\mathrm{Y}_{1}+\mathrm{e} \ldots \ldots . . . . . .(1) \\
\text { Keterangan } & \text { : } \\
\mathrm{Y}_{1} \quad=\text { Kepuasan kerja } \\
\mathrm{Y}_{2} \quad=\text { Kinerja aparatur pengawasan intern } \\
\mathrm{b}_{0} \quad=\text { Intercept } \\
\mathrm{b}_{1} \mathrm{~s} / \mathrm{d} \mathrm{b}_{2} & =\text { Koefisien regresi yang akan dihitung } \\
\mathrm{X}_{1} & =\text { Kompetensi } \\
\mathrm{X}_{2} & =\text { Kedisiplinan } \\
\mathrm{e} & =\text { Standar error. }
\end{array}
$$$$
\text { Keterangan : }
$$

3. Pengujian Hipotesis

Pengujian hipotesis atas regresi dan korelasi digunakan dengan alat analisis sebagai berikut:

a. Uji t

Uji ini adalah untuk mengetahui apakah masingmasing variabel bebas mempunyai pengaruh terhadap variabel terikat apakah bermakna atau tidak. Pengujian dilakukan dengan menggunakan pendekatan probabilitas yaitu apabila nilai sign. < 0,05 menemukan pengaruh yang signifikan antara variabel bebas dengan variabel terikat, dan apabila nilai sig > 0,05 memberikan pengaruh yang tidak signifikan antara variabel bebas dengan variabel terikat

b. Uji F

Uji $F$ ini digunakan untuk mengetahui apakah seluruh variabel bebasnya secara bersama-sama mempunyai pengaruh yang simultan terhadap variabel terikat. Pengujian dilakukan dengan melihat nilai signifikan yang lebih kecil dari 0,05 menemukan ada pengaruh yang simultan antara variabel bebas terhadap variabel terikat, begitu pula sebaliknya.

4. Koefisien determinasi (adjusted $\mathbf{R}^{2}$ ).

Uji $\mathrm{R}^{2}$ merupakan uji yang dilakukan terhadap model yang dibentuk dengan tujuan menjelaskan seberapa besar kontribusi dari variabel bebas yang diteliti terhadap variabel terikat. Nilai $R^{2}$ mempunyai range antara 0 sampai dengan $1\left(0 \leq \mathrm{R}^{2}\right.$ $\geq 1$ ). Semakin besar nilai $\mathrm{R}^{2}$ maka semakin bagus model regresi yang digunakan. Sedangkan semakin kecil nilai $\mathrm{R}^{2}$ artinya variabel bebas yang digunakan terhadap variabel terikat semakin kecil.

Uji Mediasi dengan Sobel Test 
Sobel test merupakan uji untuk mengetahui apakah hubungan yang melalui sebuah variabel mediasi secara signifikan mampu sebagai mediator dalam hubungan tersebut. Untuk menghitung nilai dari signifikasi variabel pengaruh intervening, menggunakan uji sobel (Ghozali, 2018: 247), dengan rumus sebagai berikut:

$$
z=\frac{a b}{\sqrt[a]{\left(b^{2} S E_{a}^{2}\right)+\left(a^{2} S E_{b}^{2}\right)}}
$$

Keterangan :

$$
\begin{aligned}
\mathrm{a}= & \text { Koefisien regresi variabel independen terhadap } \\
& \text { variabel mediasi } \\
\mathrm{b}= & \begin{array}{l}
\text { Koefisien regresi variabel mediasi terhadap } \\
\text { variabel dependen }
\end{array} \\
\mathrm{Sea}= & \begin{array}{l}
\text { Standar error of estimation dari pengaruh } \\
\text { variabel independen terhadap variabel mediasi. }
\end{array} \\
\mathrm{SEb}= & \begin{array}{l}
\text { Standar error of estimation dari pengaruh variabel } \\
\text { mediasi terhadap variabel dependen. }
\end{array}
\end{aligned}
$$

\section{HASIL DAN PEMBAHASAN}

1) Pengaruh Kompetensi terhadap Kepuasan Kerja Pegawai APIP pada Kantor Inspektorat Kabupaten Barru

Berdasarkan hasil analisis data penelitian yang telah dilakukan maka dapat dikatakan bahwa kompetensi pegawai APIP sudah berada dalam kategori tinggi. Dimana dilihat dari masa kerja pegawai yang berada pada rentang 5,1 - 10 tahun, hal ini dapat dikatakan bahwa pegawai APIP sudah memiliki pengalaman kerja yang dapat diandalkan dalam melakukan pekerjaan. Selain itu pegawai APIP yang bekerja pada Kantor Inspektorat Kabupaten Barru rata-rata memiliki pendidikan S1, hal ini menunjukkan bahwa pegawai sudah memiliki pengetahuan dalam bidang pekerjaan yang dikerjakan selama ini.

Kemudian dari tanggapan responden mengenai kompetensi pegawai APIP sudah dapat dikatakan bahwa pegawai APIP sudah memiliki pengetahuan sesuai dengan standar yang ditetapkan oleh Kantor Inspektorat Kabupaten Barru dan selain itu tingkat pengetahuan pegawai APIP yang sudah dapat memecahkan masalah terkait dalam pekerjaan yang ditugaskan selama ini. Selanjutnya tanggapan pegawai APIP terlihat dengan keterampilan, dimana sudah dikategorikan tinggi karena keterampilan pegawai sudah sesuai bidang pekerjaan sehari-hari dan dengan keterampilan yang dimiliki pegawai dapat meningkatkan inisiatif dalam penyelesaian pekerjaan.

Tanggapan pegawai mengenai motif, dimana pegawai lebih memiliki motivasi jika ditempatkan pada pekerjaan yang sesuai dengan bidang kompetensi yang dimiliki pegawai, dan dengan kompetensi yang dimiliki pegawai terdorong untuk bekerja lebih baik. Skor jawaban responden yang terbesar dalam penelitian ini adalah pengetahuan pegawai dalam melakukan memecahkan masalah dan penempatan pegawai yang sesuai dengan bidang kompetensi yang dimiliki oleh pegawai. Sehingga hal ini ini yang perlu dipertahankan oleh atasan Kantor Inspektorat Kabupaten Barru untuk lebih meningkatkan kompetensi pegawai. Sedangkan skor jawaban responden yang terendah adlah keterampilah pegawai yang penempatannya sesuai dengan bidang pekerjaan yang dilakukan sehari-hari, dimana masih adanya pegawai APIP yang ditempatkan tidak sesuai dengan bidang kompetensinya. Sehingga hal ini perlu mendapat perhatian atasan agar menempatkan pegawai APIP sesuai dengan bidang kompetensinya.

Hasil analisis data yang telah dilakukan bahwa kompetensi memberikan kontribusi yang positif dalam meningkatkan kepuasan kerja. Hal ini menunjukkan bahwa kompetensi yang dimiliki pegawai APIP sudah dapat meningkatkan kepuasan kerja. Semakin tinggi kompetensi pegawai APIP dengan pekerjaan yang dilakukan sehari-hari maka akan dapat memberikan dampak dengan kepuasan kerja bagi setiap pegawai APIP yang bekerja pada Kantor Inspektorat Kabupaten Barru.

Pendapat yang dikemukakan oleh Rivai dan Sagala (2010:856) bahwa kompetensi yang dimiliki saat ini oleh karyawan sangat penting dalam pencapaian tujuan organisasi dan memotivasi para karyawan untuk memberikan yang terbaik agar mendapatkan kepuasan tersendiri dalam melakukan pekerjaan. Sehingga dalam temuan penelitian yang telah sejalan dengan pendapat yang dikemukakan oleh Rivai dan Sagala (2010). Selain itu dari beberapa penelitian seperti yang dilakukan oleh Ngebu, dkk (2018), Dhermawan (2012), dan Hadiwijaya (2016) yang telah sesuai dengan ditemukan oleh peneliti bahwa kompetensi berpengaruh positif dan signifikan terhadap kepuasan kerja.

\section{2) Pengaruh Kedisiplinan Terhadap Kepuasan Kerja}

Berdasarkan hasil analisis mengenai kedisiplinan terhadap kepuasan kerja khususnya pada Kantor Inspektorat Kabupaten Barru. Dimana dilihat dari tingkat kedisiplinan pegawai sudah berada pada kategori baik. Hal ini dapat dilihat bahwa pegawai yang selalu mentaati peraturan yang telah ditetapkan oleh Kantor Inspektorat Kabupaten Barru, kemudian kerja sama yang baik antar pegawai APIP dengan atasan dan pegawai APIP dengan pegawai APIP lainnya sudah terjalin kerja sama yang baik sehingga dapat menghasilkan efektivitas kerja yang tinggi. Kemudian pegawai APIP yang telah mengambil tindakan korektif atas hasil pekerjaan sehingga dapat meningkatkan hasil kerja yang lebih baik dalam penyelesaian pekerjaan. Selain itu tingkat kehadiran pegawai yang selalu hadir tepat waktu pada jam kantor dan selain itu pegawai telah mampu untuk melaksanakan pekerjaan yang sesuai dengan waktu yang telah ditentukan.

Berdasarkan tanggapan responden mengenai tingkat kedisiplinan pegawai APIP, dimana skor jawaban responden yang terbesar dalam penelitian ini yaitu 
ketaatan pegawai dengan peraturan yang telah ditetapkan dan selain itu adalah kemampuan pegawai APIP yang telah melakukan pekerjaan sesuai dengan waktu yang telah ditentukan. Sehingga hal ini petlu dipertahankan oleh Kantor Inspektorat Kabupaten Barru guna dapat lebih meningkatkan kedisiplinan pegawai dimasa yang akan datang. Sedangkan skor jawaban responden yang terendah adalah kerja sama pegawai dalam pelaksanaan kerja, sehingga masih perlu ditingkatkan kerja sama baik antar pegawai dengan atasan maupun antar pegawai dengan pegawai lainnya pada Kantor Inspektorat Kabupaten Barru.

Hasil analisis data dalam penelitian ini yang menunjukkan bahwa kedisiplinan pegawai memberikan dampak dalam meningkatkan kepuasan kerja, dimana semakin tinggi kedisiplinan pegawai dalam bekerja maka akan dapat meningkatkan kepuasan kerja pegawai APIP dalam bekerja. Temuan penelitian ini menunjukkan bahwa kedisiplinan pegawai memberikan dampak terhadap peningkatan kepuasan kerja pegawai APIP khususnya pada Kantor Inspektorat Kabupaten Barru.

Pendapat yang dikemukakan oleh Hasibuan (2019:193) bahwa bila karyawan meningkatkan disiplin kerja yang tinggi, diharapkan akan mampu menyelesaikan tugas dengan cepat dan tepat sehingga timbul kepuasan kerja. Hal ini sesuai dengan yang ditemukan oleh peneliti bahwa disiplin kerja mempengaruhi kepuasan kerja. Sedangkan beberapa penelitian sebelumnya yaitu Hadiwijaya (2016) yang sejalan dengan yang ditemukan peneliti bahwa kedisiplinan memberikan pengaruh positif dan signifikan terhadap kepuasan kerja pegawai APIP khususnya pada Kantor Inspektorat Kabupaten Barru.

\section{3) Pengaruh Kompetensi Terhadap Kinerja Pegawai}

Berdasarkan hasil analisis data pada penelitian ini menunjukkan bahwa tingkat kompetensi yang dimiliki oleh pegawai APIP, khususnya pada Kantor Inspektorat Kabupaten Barru. Dimana semakin tinggi kompetensi pegawai dalam pelaksanaan pekerjaan maka akan memberikan pengaruh yang bermakna terhadap peningkatan kinerja pegawai. Sehingga dari hasil pengamatan yang dilakukan bahwa kompetensi yang dimiliki oleh pegawai memberikan kontribusi terhadap peningkatan kinerja pegawai APIP khususnya pada Kantor Inspektorat Kabupaten Barru.

Kemudian dari hasil analisis data dalam penelitian ini menunjukkan bahwa tingkat pengetahuan dan keterampilan pegawai APIP khususnya pada Kantor Inspektorat Kabupaten Barru sudah dapat meningkatkan kompetensi pegawai. Hal ini sejalan dengan teori yang dikemuakan oleh Prawironegoro dan Utari (2016) bahwa kompetensi merupakan perpaduan keterampilan, pengetahuan, kreativitas, dan sikap positif terhadap pekerjaan tertentu yang diwujudkan dalam pencapaian kinerja. Sedangkan Susanto (2016) menemukan bahwa kompetensi berpengaruh terhadap kinerja pegawai. Sedangkan pendapat yang dikemukakan oleh Moeheriono (2014:8) bahwa kompetensi mempunyai hubungan sebab akibat jika dikaitkan dengan kinerja seorang pegawai, serta kompetensi yang terdiri atas: motif, sifat, konsep diri, keterampilan, dan pengetahuan yang dapat memprediksikan perilaku seseorang, sehingga pada akhirnya dapat memprediksi kinerja orang tersebut. Hal ini dapat disimpulkan bahwa penelitian ini sejalan dengan yang dilakukan oleh Prawironegoro dan Utari (2016), Susanto (2016), dan Moeheriono (2014).

Sedangkan dari beberapa penelitian sebelumnya yaitu Rostarina (2016), Bahari (2019), Susanto (2016), Iskandar dan Enceng (2014) yang sejalan dengan yang diteliti oleh peneliti bahwa kompetensi berpengaruh positif dan signifikan terhadap kinerja pegawai. Dengan demikian maka hipotesis telah diuraikan sebelumnya dapat diterima.

\section{4) Pengaruh Kedisiplinan Terhadap Kinerja Pegawai}

Berdasarkan hasil analisis data penelitian yang telah dilakukan maka dapat dikatakan bahwa kedisiplinan memiliki pengaruh dalam meningkatkan kinerja pegawai. Semakin tinggi kedisiplinan pegawai dalam bekerja maka akan memberikan kontribusi dalam meningkatkan kinerja pegawai APIP pada Kantor Inspektorat di Kabupaten Barru.

Hasil temuan dalam penelitian ini yang memberikan indikasi faktor yang dapat meningkatkan kinerja pegawai APIP adalah kedisiplinan, hal ini sejalan dengan teori kedisiplinan seperti yang dikemukakan oleh Hartatik (2012) bahwa disiplin kerja yang baik mencerminkan besarnya tanggungjawab seseorang terhadap tugas-tugas yang diberikan kepadanya. Jadi, dapatlah dikatakan bahwa disiplin kerja memiliki andil yang sangat besar terhadap kinerja seorang pegawai, sehingga dari pendapat Hartatik (2014) bahwa disiplin kerja berpengaruh dalam meningkatkan kinerja pegawai.

Beberapa penelitian sebelumnya yaitu Susanto (2016), Rizal, dkk (2019), dan Hadiwijaya (2016) bahwa kedisiplinan berpengaruh positif dan signifikan terhadap kinerja pegawai. Sehingga dalam penelitian ini yang sejalan dengan penelitan yang dilakukan oleh Susanto (2016), Rizal, dkk (2019) dan Hadiwijaya (2016). Dengan demikian hipotesis dalam penelitian ini dapat diterima.

\section{5) Pengaruh Kepuasan Kerja Terhadap Kinerja Pegawai}

Hasil analisis data dalam penelitian ini yang menunjukkan bahwa kepuasan kerja berpengaruh terhadap peningkatan kinerja pegawai. Hal ini didasari dari penempatan pegawai APIP mengenai kepuasan kerja, dimana kepuasan yang dirasakan oleh pegawai selama bekerja pada Kantor Inspektorat di Kabupaten Barru sudah baik. Terkait dengan pekerjaan pegawai yang sesuai dengan harapan pegawai dalam bekerja, hal ini 
disebabkan karena pegawai yang bekerja sesuai dengan bidang kompetensi pegawai yang dilakukan selama ini dan selain itu gaji pegawai yang sesuai dengan kebutuhan hidup keluarga.

Kemudian kepuasan yang dirasakan oleh pegawai APIP terlihat dengan kebijakan promosi jabatan yang sesuai dengan harapan pegawai. Sedangkan penempatan pegawai, dimana pegawai APIP yang sesuai dengan kesempatan terbuka untuk dapat dipromosikan sesuai sedangkan dari jawaban responden terlihat dengan atasan memberikan pengarahan kepada bawahan dalam bekerja yang telah meningkatkan kepuasan bagi pegawai yang bekerja pada Kantor Inspektorat di Kabupaten Barru. Begitupula dengan umpan balik dari atasan dengan pekerjaan yang telah menimbulkan kepuasan bagi pegawai APIP.

Skor jawaban responden dari setiap item pernyataan yang tertinggi adalah umpan balik dari pekerjaan yang dilakukan oleh pegawai. Hal ini perlu dipertahankan oleh atasan Kantor Inspektorat di Kabupaten Barru terkait dengan umpan balik pegawai dengan pekerjaan pegawai. Sedangkan dalam skor jawaban responden yang terendah adalah kepuasan pegawai dengan promosi jabatan, hal ini perlu ditingkatkan guna dapat meningkatkan kepuasan kerja pegawai APIP pada Kantor Inspektorat di Kabupaten Barru.

Hasil analisis data dalam penelitian ini yang menunjukkan bahwa kepuasan kerja dapat memberikan pengaruh secara nyata dalam meningkatkan kinerja APIP. Hal ini dapat dilihat bahwa semakin tinggi kepuasan kerja maka akan dapat meningkatkan kinerja pegawai. Dalam hubungannya dengan uraian tersebut diatas maka dapat dikatakan bahwa kepuasan kerja dapat meningkatkan kinerja pegawai APIP khususnya pada Kantor Inspektorat di Kabupaten Barru.

Beberapa pendapat yang salah satunya dikemukakan oleh Sinambela (2012:255) bahwa kepuasan kerja berkaitan erat dengan kinerja peagwai, sedangkan pendapat dari Robbins (2015:91) bahwa kepuasan kerja yang tinggi akan berpengaruh terhadap kinerja pegawai. Sehingga dari yang ditemukan peneliti yang telah sejalan dengan pendapat Robbins (2015) dan Sinambela (2012), sedangkan dari beberapa penelitian sebelumnya yaitu Dhermawan (2012), Rizal, dkk (2019), dan Hadiwijaya (2016) bahwa kepuasan pegawai berpengaruh positif dan signifikan terhadap kinerja pegawai. Hal ini sejalan dengan yang ditemukan oleh penelitian sebelumnya. Dalam kaitannya dengan uraian tersebut diarikan bahwa hipotesis yang telah dikemukakan sebelumnya dapat dikatakan terbukti dan diterima.

\section{6) Pengaruh Kompetensi Terhadap Kinerja Pegawai Melalui Kepuasan Kerja}

Hasil analisis data dalam penelitian ini menunjukkan bahwa kompetensi telah meningkatkan kinerja pegawai melalui kepuasan kerja. Hal ini dapat dikatakan bahwa kompetensi dapat meningkatkan kepuasan kerja sehingga memberikan dampak terhadap kinerja APIP khususnya pada Kantor Inspektorat di Kabupaten Barru.

Kemudian dalam temuan pada penelitian ini menunjukkan bahwa analisis sobel test, dimana baik pengaruh langsung maupun pengaruh tidak langsung berpengaruh secara signifikan terhadap kinerja pegawai melalui kepuasan kerja. Temuan ini dapat mengindikasikan bahwa kepuasan kerja dapat memediasi secara parsial pengaruh kompetensi terhadap kinerja APIP pada Kantor Inspektorat di Kabupaten Barru. Dengan demikian dalam penelitian ini maka hipotesis diterima.

\section{7) Pengaruh Kedisiplinan Terhadap Kinerja Pegawai Melalui Kepuasan Kerja}

Hasil analisis data pada penelitian ini yang menunjukkan bahwa kedisiplinan berpengaruh positif dan signifikan terhadap kinerja APIP melalui kepuasan kerja. Hal ini dapat dikatakan bahwa kedisiplinan dapat memediasi pengaruh kedisiplinan terhadap kinerja APIP pada Kantor Inspektorat di Kabupaten Barru. Temuan dalam penelitian ini menunjukkan bahwa baik pengaruh langsung maupun pengaruh tidak langsung kedisiplinan berpengaruh terhadap kinerja APIP melalui kepuasan kerja, sehingga dapat dikatakan bahwa kepuasan kerja dapat memediasi scara parsial kedisplinan terhadap kinerja APIP pada Kantor Inspektorat di Kabupaten Barru.

\section{KESIMPULAN DAN SARAN}

Hasil penelitian dapat disimpulkan bahwa pengaruh kompetensi terhadap kepuasan kerja, dimana temuan penelitian ini menunjukkan bahwa kompetensi memberikan pengaruh secara nyata terhadap peningkatan kepuasan kerja bagi pegawai APIP Kantor Inspektorat di Kabupaten Barru. Pengaruh kedisiplinan terhadap kepuasan pegawai, hal ini menemukan bahwa secara empirik kedisiplinan memberikan pengaruh secara nyata terhadap peningkatan kepuasan kerja pada Kantor Inspektorat di Kabupaten Barru. Pengaruh kompetensi terhadap kinerja APIP, hal ini menunjukkan bahwa kompetensi dapat meningkatkan kinerja APIP khususnya pada kantor inspektorat di kabupaten barru. semakin tinggi kompetensi maka akan semakin tinggi pula kinerja APIP pada Kantor Inspektorat di Kabupaten Barru. Pengaruh kedisiplinan terhadap kinerja APIP, temuan dari penelitian ini menunjukkan bahwa kedisiplinan memberikan dampak terhadap peningkatan kinerja pegawai. semakin tinggi kedisiplinan maka semakin tinggi pula kinerja APIP. Pengaruh kepuasan kerja terhadap kinerja APIP

\section{DAFTAR PUSTAKA}

Anak Agung Ngurah Bagus Dhermawan, (2012) Pengaruh Motivasi, Lingkungan Kerja, Kompetensi, 
dan Kompensasi Terhadap Kepuasan Kerja dan Kinerja Pegawai di Lingkungan Kantor Dinas Pekerjaan Umum Provinsi Bali. Jurnal Manajemen Home Archives, Vol.6 No.2 (2012)

Ghozali, Imam, 2018. Aplikasi Analisis Multivariat dengan Program IBM SPSS 25. Cetakan kesembilan, edisi kesembilan, Penerbit : Universitas Diponegoro, Semarang

Hamali, Yusuf Arif. 2016. Pemahaman Manajemen Sumber Daya Manusia Strategi Mengelola Karyawan. Penerbit : CAPS, Jakarta

Hasibuan, S.P. Malayu. 2019. Manajemen Sumber Daya Manusia. Edisi Revisi, Cetakan Kedua puluh tiga. Penerbit : Bumi Aksara, Jakarta

Hendra Hadiwijaya (2016) Pengaruh Kompetensi Dan Disiplin Terhadap Kepuasan Serta Implikasinya Pada Prestasi Kerja Karyawan. Jurnal Manajemen dan Bisnis Sriwijaya Vol. 14, No.3 September (2016).

Irna Anggriana Bahari, (2019) Pengaruh Kompetensi dan Insentif Terhadap Kinerja Melalui Kepuasan Kerja Pegawai Dinas Kesehatan Kabupaten Bulukumba. Journal of Management, Beranda Vol. 2, No.3 (2019).

Mangkunegara, AA. Anwar Prabu, 2017, Manajemen Sumber Daya Manusia Perusahaan, Penerbit : Remaja Rosdakarya, Bandung

Moeheriono. 2014. Pengukuran Kinerja Berbasis Kompetensi Edisi Revisi. Penerbit : Rajagrafindo Persada. Jakarta

Muamar, (2019) Pengaruh Kepuasan Kerja, Disiplin Kerja, dan Budaya Kerja Terhadap Kinerja Pegawai pada Dinas Tenaga Kerja dan Transmigrasi Provinsi Sulawesi Tengah. e Jurnal Katalogis, Volume 5 Nomor 7, Juli 2017 hlm 9 -16ISSN: 2302-2019

Muh Rizal S, dkk (2019) Kompetensi, Kedisiplinan, Motivasi dan kepuasan Kerja Terhadap Kinerja Pegawai Pinisi Business Administration Review Vol. 1, No. 2, September 2019, Hal 93-100 ISSN (Print): 2656-6524. Homepage: http://ojs.unm.ac.id/ index.php/pbar/index.

Prawironegoro dan Utari. 2016. Manajemen SDM abad 21, edisi revisi. Penerbit : Mitra Wacana Media. Jakarta

Rina Rostarina, (2016) Pengaruh Kompetensi Pegawai Terhadap Kinerja Pegawai pada Balai Pelatihan Kesehatan Dinas Kesehatan Provinsi Jawa Barat. Pengaruh Kompetensi Pegawai Terhadap Kinerja Pegawai Pada Balai Pelatihan Kesehatan Dinas Kesehatan Provinsi Jawa Barat. Tesis Universitas Pasundan

Rivai Veithazal, Zainal, H. Mansyur Ramly, Willy Arafah, 2015. Manajemen Sumber Daya Manusia Untuk Perusahaan Dari Teori ke Praktik. Penerbit : Rajawali Pers, Jakarta
Rivai, Veithzal., dan Sagala Jauvani. 2014. Manajemen Sumber Daya Manusia Untuk Perusahaan, Penerbit : Rajawali Pers. Jakarta

Satrio Dedy Susanto, (2016) Pengaruh Kompetensi. Disiplin Kerja, Kompensasi, dan Kepuasan Kerja Terhadap Kinerja Pegawai (Study Kasus Pada Pegawai PT Safta Tours. Universitas Islam Negeri Sarif Bidayatullah Jakarta.

Sentot Iskandar, Enceng Juhana (2014) Pengaruh Kompetensi dan Lingkungan Kerja Terhadap Kepuasan Kerja Serta Implikasinya pada Kinerja Guru di SDN Baros Mandiri 5 Kota Cimahi Jurnal Ekonomi, Bisnis \& Entrepreneurship Vol. 8, No. 2, Oktober 2014, 86-98ISSN2443-0633.

Sinambela, Lijan Poltak. 2017. Manajemen Sumber Daya Manusia. Penerbit : Bumi Aksara, Jakarta

Sugiyono. 2016. Statistik Untuk Penelitian. Cetakan Kedua Puluh Tujuh, Penerbit : Alfabeta, Bandung.

Sunyoto, Danang. 2015. Penelitian Sumber Daya Manusia: Teori, Kuesioner, Alat Statistik dan Contoh Riset. Penerbit : CAPS (Center of Academic Publishing Service), Yogyakarta

Wahyu Yulianto, (2018) Pengaruh Pelatihan, Kompetensi, Motivasi dan Kepemimpinan Terhadap Kinerja Pegawai Dengan Pendidikan Sebagai Pemoderator Pada Balai Pendidikan dan Pelatihan Aparatur Kementerian Kelautan dan Perikanan. Jurnal Ekonomi dan Bisnis, Vol. 9 No. 1 September 2018. ISSN : 2503-4413, Hal 37 - 49

Wilfridus Djaga Ngebu, dkk (2018) Pengaruh Kompetensi dan Penempatan Pegawai Terhadap Kepuasan dan Kinerja Pegawai. E-Jurnal Ekonomi dan Bisnis Universitas Udayana 7.12 (2018):25552570. ISSN: 2337-3067. 